\title{
New Neolignans from Spiraea formosana
}

\author{
Tian-Shung Wu, ${ }^{*, a, b}$ Chia-Chan Hwang, ${ }^{a}$ Ping-Chung Kuo, ${ }^{c}$ Tsung-Hsiao Kuo, ${ }^{a}$ \\ Amooru Gangaiah DAMU, ${ }^{a}$ and Chung-Ren $\mathrm{Su}^{a}$ \\ ${ }^{a}$ Department of Chemistry, National Cheng Kung University; Tainan 701, Taiwan, R.O.C.: ${ }^{b}$ National Research Institute of \\ Chinese Medicine; Taipei 112, Taiwan, R.O.C.: and ${ }^{c}$ Department of Biotechnology, National Huwei University of Science \\ and Technology; Yunlin 632, Taiwan, R.O.C. Received July 3, 2004; accepted July 29, 2004
}

\begin{abstract}
Phytochemical investigation on the ethanol extract from the stems of Spiraea formosana has resulted in the isolation of four new neolignans, named spiraformin-A, -B, -C and -D (1-4), together with thirty five known compounds. Their structures were established primarily on the basis of 1D and 2D NMR spectral and chemical transformation methods.
\end{abstract}

Key words Spiraea formosana; Rosaceae; neolignan; methylation; Gibb's test

Spiraea formosana HAYATA is an endemic shrub of Rosaceae distributed widely in high altitudes of forests in central Taiwan. ${ }^{1)}$ The young leaves, fruits and roots of Spiraea species have been used as diuretic, detoxicant, and analgesic agents and for the treatment of inflammation, cough, headache and toothache in traditional Chinese medicine., ${ }^{2,3)}$ Roots of Spiraea species are also known to use traditionally for the treatments of malaria, fever and emetic conditions. ${ }^{4,5)}$ Some of Spiraea species reported to exhibit potent antiplatelet aggregation activities induced by PAF and $\mathrm{AA},{ }^{6}$ and also inhibition of generation of nitric oxide and superoxide in RAW 264.7 cells. $^{7,8)}$ Several Spiraea species of Japan origin were reported to have high allelopathic potential. ${ }^{9)}$ Plants in this genus are known to produce various diterpene alkaloids of atisine and hetisine types, ${ }^{10-17)}$ and some of them significantly inhibited rabbit platelet aggregation induced by PAF and AA in vitro and ex vivo. ${ }^{6}$ Some of these diterpene alkaloids also exhibited protective effects on cerebral ischemia-reperfusion injury in gerbils. ${ }^{18)}$ The members of Spiraea are also shown to contain benzaldehydes, cinnamoyl glucosides, flavonoids, terpenoids and terpenoid glycosides. ${ }^{19-23)}$ An acetylated derivative of a unique terpene glycoside, prunioside A from Spiraea species is reported to inhibit nitric oxide production in murine macrophage-like RAW 264.7 cells. ${ }^{24)}$ However, little is known concerning the chemical constituents of $S$. formosana. As a part of serial studies on the Formosan endemic plants, we have undertaken the investigation of the chemical components of the stems of $S$. formosana and isolated thirty nine compounds including four new neolignans. Details of the isolation and structural determination of new neolignans $(\mathbf{1}-\mathbf{4})$ are presented here.

\section{Results and Discussion}

Fresh stems of $S$. formosana were extracted with hot ethanol. The water suspension of the original ethanol extract was subjected to a liquid-liquid partition to obtain $\mathrm{CHCl}_{3}, n$ $\mathrm{BuOH}$ and water subfractions. Four new biphenyl ether neolignans together with thirty five known compounds were separated from these subfractions by a combination of chromatographic techniques. New neolignans were characterized as dimers of trans-4-hydroxycinnamic acid, an important lignin precursor, which were isolated for the first time from the natural sources. However, Katase et al. reported the transformation of trans-4-hydroxycinnamic acid by a laccaase of the fungus Trametes versicolor to its oxidative coupling compound or dimer. ${ }^{25}$

Spiraformin A (1), a colorless syrup was shown to have a molecular formula of $\mathrm{C}_{20} \mathrm{H}_{20} \mathrm{O}_{6}$ by high resolution electron impact mass spectrum (HR-EI-MS), ([M $]^{+}, m / z$ 356.1259) which was consistent with ${ }^{13} \mathrm{C}$-NMR and DEPT experiments. The UV spectrum of $\mathbf{1}$ in $\mathrm{MeOH}$ showed absorption maxima at 223 and $313 \mathrm{~nm}$ characteristic of cinnamoyl chromophore. ${ }^{26)}$ The IR absorption bands at 3426 and $1710 \mathrm{~cm}^{-1}$ indicated the presence of hydroxyl and carbonyl functions, respectively. A 1,3,4-trisubstituted phenyl group was observed in the ${ }^{1} \mathrm{H}$ - and ${ }^{13} \mathrm{C}-\mathrm{NMR}$ spectra [ABX system at $\delta 6.98$ $(1 \mathrm{H}, \mathrm{d}, J=2.0 \mathrm{~Hz}, \mathrm{H}-2), 7.03(1 \mathrm{H}, \mathrm{d}, J=8.0 \mathrm{~Hz}, \mathrm{H}-5)$, and $7.20(1 \mathrm{H}, \mathrm{dd}, J=8.0,2.0 \mathrm{~Hz}, \mathrm{H}-6)$, and $\delta 116.0(\mathrm{C}-2), 116.5$ (C-6), 125.2 (C-5), 127.6 (C-1), 149.4 (C-3) and 154.5 (C4)] and the attachment of a-CH $=\mathrm{CH}-\mathrm{COOCH}_{3}$ group to the aromatic nucleus was evidenced by signals at $\delta 6.17(1 \mathrm{H}, \mathrm{d}$, $J=16.0 \mathrm{~Hz}, \mathrm{H}-8), 7.52(1 \mathrm{H}, \mathrm{d}, J=16.0 \mathrm{~Hz}, \mathrm{H}-7)$ and 3.67 $(3 \mathrm{H}, \mathrm{s}, \mathrm{OMe}-10) ; \delta 144.3$ (C-7), 115.8 (C-8), 173.3 (C-9) and $51.8\left(\mathrm{OCH}_{3}-10\right)$, and ${ }^{3} \mathrm{~J}$-HMBC connectivities from $\mathrm{H}-7$ to $\mathrm{C}-2$ and from $\mathrm{OCH}_{3}-10$ to $\mathrm{C}-9$, thus confirming the presence of a phenyl propenoyl derivative. The ${ }^{1} \mathrm{H}$ - and ${ }^{13} \mathrm{C}-\mathrm{NMR}$ spectra of 1 also revealed the presence of a para substituted phenyl group $\left[\mathrm{A}_{2} \mathrm{~B}_{2}\right.$ system at $\delta 6.96\left(2 \mathrm{H}, \mathrm{d}, J=8.4 \mathrm{~Hz}, \mathrm{H}-3^{\prime}\right.$, $\left.-5^{\prime}\right)$ and $7.21\left(2 \mathrm{H}, \mathrm{d}, J=8.4 \mathrm{~Hz}, \mathrm{H}-2^{\prime},-6^{\prime}\right), \delta 118.4\left(\mathrm{C}-3^{\prime}\right.$, $\left.-5^{\prime}\right), 130.1\left(\mathrm{C}-2^{\prime},-6^{\prime}\right), 136.8\left(\mathrm{C}-1^{\prime}\right)$ and $\left.144.6\left(\mathrm{C}-4^{\prime}\right)\right]$ to which is attached a $-\mathrm{CH}_{2} \mathrm{CH}_{2} \mathrm{COOCH}_{3}$ group $[\delta 2.65(2 \mathrm{H}, \mathrm{t}$, $\left.J=8.0 \mathrm{~Hz}, \mathrm{H}-8^{\prime}\right), 2.96\left(2 \mathrm{H}, \mathrm{t}, J=8.0 \mathrm{~Hz}, \mathrm{H}-7^{\prime}\right)$ and $3.75(3 \mathrm{H}$, s, $\left.\mathrm{OCH}_{3}-10^{\prime}\right) ; \delta 29.9\left(\mathrm{C}-7^{\prime}\right), 35.9\left(\mathrm{C}-8^{\prime}\right), 51.9\left(\mathrm{OCH}_{3}-10^{\prime}\right)$ and $173.5\left(\mathrm{C}-9^{\prime}\right)$ ] as evidenced by HMBCs from $\mathrm{H}-7^{\prime}$ to $\mathrm{C}-$ $2^{\prime}, \mathrm{C}-1^{\prime}$, and $\mathrm{C}-9^{\prime}$. These data indicated the presence of a second phenylpropanoyl moiety leading to 1 being a neolignan. These two moieties were connected with ether linkage was suggested by the molecular formula and the two oxygenated quaternary aromatic carbons at $\delta 144.6\left(\mathrm{C}-4^{\prime}\right)$ and 149.4 (C-3). The negative Gibb's test for compound 1 indicated that the para-position of free hydroxyl group was substituted with the olefinic fragment, so that C-3 should be involved in ether linkage. To further confirm the position of free hydroxyl group and thus the site of ether linkage, compound 1 was methylated with iodomethane in acetone solution. The resulting compound exhibited one more methoxy group at $\delta 3.67(3 \mathrm{H}, \mathrm{s})$. This methoxy signal displayed NOESY correlation with the proton signal at $\delta 7.03$ (H-5) 
Table 1. ${ }^{1} \mathrm{H}$ - and ${ }^{13} \mathrm{C}-\mathrm{NMR}$ Data of Compounds $\mathbf{1}-\mathbf{4}^{a}$

\begin{tabular}{|c|c|c|c|c|c|c|c|c|}
\hline & \multicolumn{2}{|l|}{1} & \multicolumn{2}{|l|}{2} & \multicolumn{2}{|l|}{3} & \multicolumn{2}{|l|}{$\mathbf{4}^{b)}$} \\
\hline & $\mathrm{H}$ & $\mathrm{C}$ & $\mathrm{H}$ & $\mathrm{C}$ & $\mathrm{H}$ & $\mathrm{C}$ & $\mathrm{H}$ & $\mathrm{C}$ \\
\hline 1 & & 127.6 & & 126.3 & & 127.3 & & 109.5 \\
\hline 2 & $6.98(1 \mathrm{H}, \mathrm{d}, 2.0)$ & 116.0 & $6.98(1 \mathrm{H}, \mathrm{d}, 2.0)$ & 116.3 & $6.98(1 \mathrm{H}, \mathrm{d}, 2.0)$ & 116.3 & $7.16(1 \mathrm{H}, \mathrm{d}, 2.0)$ & 119.6 \\
\hline 3 & & 149.4 & & 144.4 & & 146.5 & & 146.7 \\
\hline 4 & & 154.5 & & 149.3 & & 150.2 & & 150.8 \\
\hline 5 & $7.03(1 \mathrm{H}, \mathrm{d}, 8.0)$ & 125.2 & $7.03(1 \mathrm{H}, \mathrm{d}, 8.0)$ & 123.1 & $7.03(1 \mathrm{H}, \mathrm{d}, 8.0)$ & 123.1 & $7.28(1 \mathrm{H}, \mathrm{d}, 8.0)$ & 117.2 \\
\hline 6 & $7.20(1 \mathrm{H}, \mathrm{dd}, 8.0,2.0)$ & 116.5 & $7.20(1 \mathrm{H}, \mathrm{dd}, 8.0,2.0)$ & 118.8 & $7.20(1 \mathrm{H}, \mathrm{dd}, 8.0,2.0)$ & 118.9 & $7.36(1 \mathrm{H}, \mathrm{dd}, 8.0,2.0)$ & 124.8 \\
\hline 7 & $7.52(1 \mathrm{H}, \mathrm{d}, 16.0)$ & 144.3 & $7.52(1 \mathrm{H}, \mathrm{d}, 16.0)$ & 138.2 & $7.52(1 \mathrm{H}, \mathrm{d}, 16.0)$ & 139.2 & $7.55(1 \mathrm{H}, \mathrm{d}, 16.0)$ & 144.0 \\
\hline 8 & $6.17(1 \mathrm{H}, \mathrm{d}, 16.0)$ & 115.8 & $6.17(1 \mathrm{H}, \mathrm{d}, 16.0)$ & 114.5 & $6.17(1 \mathrm{H}, \mathrm{d}, 16.0)$ & 112.1 & $6.30(1 \mathrm{H}, \mathrm{d}, 16.0)$ & 116.4 \\
\hline 9 & & 167.4 & & 167.7 & & 170.3 & & 167.9 \\
\hline 10 & $3.67(3 \mathrm{H}, \mathrm{s})$ & 51.8 & $3.75(3 \mathrm{H}, \mathrm{s})$ & 51.3 & $3.75(3 \mathrm{H}, \mathrm{s})$ & 51.9 & & \\
\hline $1^{\prime}$ & & 136.8 & & 134.3 & & 136.2 & & 137.4 \\
\hline $2^{\prime}, 6^{\prime}$ & $7.21(2 \mathrm{H}, \mathrm{d}, 8.4)$ & 130.1 & $7.21(2 \mathrm{H}, \mathrm{d}, 8.4)$ & 130.1 & $7.21(2 \mathrm{H}, \mathrm{d}, 8.4)$ & 130.2 & $7.21(2 \mathrm{H}, \mathrm{d}, 8.4)$ & 129.4 \\
\hline $3^{\prime}, 5^{\prime}$ & $6.96(2 \mathrm{H}, \mathrm{d}, 8.4)$ & 118.4 & $6.96(2 \mathrm{H}, \mathrm{d}, 8.4)$ & 119.9 & $6.96(2 \mathrm{H}, \mathrm{d}, 8.4)$ & 119.9 & $6.87(2 \mathrm{H}, \mathrm{d}, 8.4)$ & 117.7 \\
\hline $4^{\prime}$ & & 144.6 & & 142.5 & & 144.3 & & 155.7 \\
\hline $7^{\prime}$ & $2.96(2 \mathrm{H}, \mathrm{t}, 8.0)$ & 29.9 & $2.96(2 \mathrm{H}, \mathrm{t}, 8.0)$ & 30.4 & $2.96(2 \mathrm{H}, \mathrm{t}, 8.0)$ & 30.6 & $2.87(2 \mathrm{H}, \mathrm{t}, 8.0)$ & 31.7 \\
\hline $8^{\prime}$ & $2.65(2 \mathrm{H}, \mathrm{t}, 8.0)$ & 35.9 & $2.65(2 \mathrm{H}, \mathrm{t}, 8.0)$ & 35.2 & $2.65(2 \mathrm{H}, \mathrm{t}, 8.0)$ & 35.9 & $2.44(2 \mathrm{H}, \mathrm{t}, 8.0)$ & 39.6 \\
\hline $9^{\prime}$ & & 173.5 & & 173.5 & & 175.4 & & 172.3 \\
\hline $10^{\prime}$ & $3.75(3 \mathrm{H}, \mathrm{s})$ & 51.9 & $4.13(2 \mathrm{H}, \mathrm{q}, 7.2)$ & 51.3 & $4.09(2 \mathrm{H}, \mathrm{t}, 6.8)$ & 59.5 & & \\
\hline $11^{\prime}$ & & & $1.25(3 \mathrm{H}, \mathrm{t}, 7.2)$ & 27.0 & $1.61(2 \mathrm{H}, \mathrm{m})$ & 26.8 & & \\
\hline $12^{\prime}$ & & & & & $1.55(2 \mathrm{H}, \mathrm{m})$ & 22.7 & & \\
\hline $13^{\prime}$ & & & & & $0.92(3 \mathrm{H}, \mathrm{t}, 7.4)$ & 19.1 & & \\
\hline $1^{\prime \prime}$ & & & & & & & $5.02(1 \mathrm{H}, \mathrm{d}, 7.6)$ & 100.8 \\
\hline $2^{\prime \prime}$ & & & & & & & $3.55-3.86(5 \mathrm{H}, \mathrm{m})$ & 73.6 \\
\hline $3^{\prime \prime}$ & & & & & & & & 76.7 \\
\hline $4^{\prime \prime}$ & & & & & & & & 70.0 \\
\hline $5^{\prime \prime}$ & & & & & & & & 77.3 \\
\hline $6^{\prime \prime}$ & & & & & & & & 61.2 \\
\hline
\end{tabular}

a) Chemical shifts are shown as $\delta$ values recorded by $400 \mathrm{MHz}$ NMR in $\mathrm{CDCl}_{3}$ with reference to tetramethylsilane (TMS), and coupling constants ( $J$ ) are expressed in Hertz $(\mathrm{Hz})$. Signal multiplicities are represented by s (singlet), br (broad), d (doublet), t (triplet), q (quartet), dd (doublets of doublet), and $\mathrm{m}$ (multiplet). $b$ ) $\mathrm{In} \mathrm{CD}_{3} \mathrm{OD}$.

confirmed that the free hydroxyl group was located at C-4 and thus carbons $\mathrm{C}-3$ and $\mathrm{C}-4$ ' were involved in the ether linkage between two phenylpropanoid moieties. Accordingly 1 was confirmed to be a new neolignan 3-p-methyldihydrocoumaroyloxy methyl- $p$-coumarate and assigned the trivial name spiraformin A.

The second lignan, compound $\mathbf{2}$ was isolated as a colorless syrup. It has the molecular formula of $\mathrm{C}_{21} \mathrm{H}_{22} \mathrm{O}_{6}$ based on HR-EI-MS analysis $\left([\mathrm{M}]^{+}, m / z \quad 370.1414\right)$ which was 14 mass units more than that of $\mathbf{1}$. The UV absorption maxima and IR absorption bands of $\mathbf{2}$ were similar to those in $\mathbf{1}$ at 230 and $285 \mathrm{~nm}$, and 3374 and $1723 \mathrm{~cm}^{-1}$, respectively, indicated that 2 has similar basic skeleton and functionalities. Analysis of the ${ }^{1} \mathrm{H}-\mathrm{NMR}$ data showed that $\mathbf{2}$ had spectral data very similar to those of $\mathbf{1}$, indicating a close structural relationship. In the ${ }^{1} \mathrm{H}-\mathrm{NMR}$ spectrum of $\mathbf{1}$ and $\mathbf{2}$ the evident difference between them the signal of one methoxy group was changed to an ethoxy group $\left[\delta 1.25\left(3 \mathrm{H}, \mathrm{t}, J=7.2 \mathrm{~Hz}, \mathrm{CH}_{3}\right.\right.$ $\left.11^{\prime}\right)$ and $\left.4.13\left(2 \mathrm{H}, \mathrm{q}, J=7.2 \mathrm{~Hz}, \mathrm{CH}_{2}-10^{\prime}\right)\right]$. The observation of ${ }^{3} J$-correlation between $\mathrm{CH}_{2}-10^{\prime}\left(\delta\right.$ 4.13) and $\mathrm{C}-9^{\prime}(\delta$ $173.5)$ in the HMBC spectrum of 2 confirmed the connection of the ethoxy group with C-9' of dihydrocoumaroyl moiety. Thus, $\mathbf{2}$ was determined to be 3-p-ethyldihydrocoumaroyloxy methyl- $p$-coumarate and was assigned the trivial name spiraformin B.

Spiraformin $\mathrm{C}$ (3) a colorless syrup had a molecular formula of $\mathrm{C}_{23} \mathrm{H}_{26} \mathrm{O}_{6}$ as determined by HR-EI-MS ([M] $]^{+}, m / z$ 398.1731). The UV and IR spectra of 3 were also similar with those of $\mathbf{1}$. Its NMR spectral data was very similar to those of $\mathbf{1}$ indicating the same basic skeleton for $\mathbf{3}$. However,

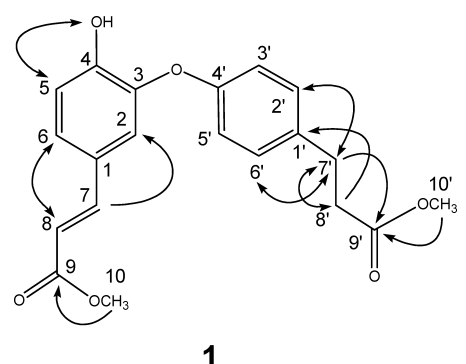

Fig. 1. HMBC $(\rightarrow)$ and NOESY $(\leftrightarrow)$ Correlations of Compound 1

in compound 3, a set of signals for $n$-butyloxy group was found at $\delta 0.92\left(3 \mathrm{H}, \mathrm{t}, J=7.4 \mathrm{~Hz}, \mathrm{CH}_{3}-13^{\prime}\right), 1.55(2 \mathrm{H}, \mathrm{m}$, $\left.\mathrm{CH}_{2}-12^{\prime}\right), 1.61\left(2 \mathrm{H}, \mathrm{m}, \mathrm{CH}_{2}-11^{\prime}\right)$, and $4.09(2 \mathrm{H}, \mathrm{t}, J=6.8 \mathrm{~Hz}$, $\left.\mathrm{CH}_{2}-10^{\prime}\right)$ instead of a methoxy signal. The evident difference in the molecular formula and the NMR signals between 3 and 1 concluded that one methyl ester group was changed to $n$-butyl ester group in 3. The HMBC correlations of methylene protons at $\delta 4.09\left(\mathrm{CH}_{2}-10^{\prime}\right)$ with $\mathrm{C}-9^{\prime}(\delta$ 175.4) and $\mathrm{CH}_{3}-10(\delta 3.75)$ with $\mathrm{C}-9(\delta$ 170.3) confirmed that the $n$ butyl ester was connected with $\mathrm{C}-9^{\prime}$. Thus the structure of $\mathbf{3}$ was assumed to be 3- $p$ - $n$-butyldihydrocoumaroyloxy methyl$p$-coumarate and named as spiraformin $\mathrm{C}$.

Compound $\mathbf{4}$ obtained as optically active colorless syrup, $[\alpha]_{\mathrm{D}}^{25}-2.1^{\circ}$, was shown to have the molecular formula $\mathrm{C}_{24} \mathrm{H}_{26} \mathrm{O}_{11}$ as deduced by the HR-FAB-MS ( $\mathrm{m} / \mathrm{z}$ 491.1554). The UV absorption maxima of 4 at 222 and $289 \mathrm{~nm}$ was typical of a cinnamoyl derivative. ${ }^{26)}$ The IR absorption bands at 3464 and $1695 \mathrm{~cm}^{-1}$ suggested the existence of hydroxyl and 


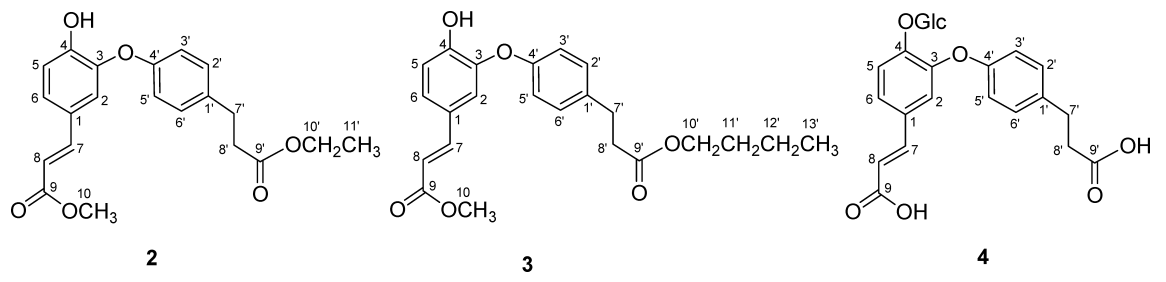

Fig. 2. Structures of $\mathbf{2}-\mathbf{4}$

carboxylic acid functionalities, respectively. The ${ }^{1} \mathrm{H}-\mathrm{NMR}$ spectrum of 4 displayed an ABX system resonated at $\delta 7.16$ $(1 \mathrm{H}, \mathrm{d}, J=2.0 \mathrm{~Hz}, \mathrm{H}-2), 7.28(1 \mathrm{H}, \mathrm{d}, J=8.0 \mathrm{~Hz}, \mathrm{H}-5)$, and $7.36(1 \mathrm{H}, \mathrm{dd}, J=8.0,2.0 \mathrm{~Hz}, \mathrm{H}-6)$; an $\mathrm{A}_{2} \mathrm{~B}_{2}$ system at $\delta 6.87$ $\left(2 \mathrm{H}, \mathrm{d}, J=8.4 \mathrm{~Hz}, \mathrm{H}-3^{\prime},-5^{\prime}\right)$ and $7.21(2 \mathrm{H}, \mathrm{d}, J=8.4 \mathrm{~Hz}, \mathrm{H}-$ $\left.2^{\prime},-6^{\prime}\right)$; two trans-coupled doublets at $\delta 6.30(1 \mathrm{H}, \mathrm{d}$, $J=16.0 \mathrm{~Hz}, \mathrm{H}-8)$ and $7.55(1 \mathrm{H}, \mathrm{d}, J=16.0 \mathrm{~Hz}, \mathrm{H}-7)$; and two mutually coupled triplets at $\delta 2.44\left(2 \mathrm{H}, \mathrm{t}, J=8.0 \mathrm{~Hz}, \mathrm{H}-8^{\prime}\right)$ and $2.87\left(2 \mathrm{H}, \mathrm{t}, J=8.0 \mathrm{~Hz}, \mathrm{H}-7^{\prime}\right)$ as in 1 indicating that the basic neolignan skeleton is same with that of 1 . Compound 4 differs from 1 by an anomeric proton signal at $\delta 5.02(1 \mathrm{H}, \mathrm{d}$, $\left.J=7.6 \mathrm{~Hz}, \mathrm{H}-1^{\prime \prime}\right)$, a five proton multiplet at $\delta 3.86-3.55$ for $\beta$-D-glucopyranosyl unit and by lacking of two methoxy singlets. Accordingly, the ${ }^{13} \mathrm{C}-\mathrm{NMR}$ spectrum of $\mathbf{4}$ revealed the signals for a glucose unit together with 18 carbon signals for the aglycone as expected. In the $2 \mathrm{D}$ analyses, the anomeric proton correlated to the aromatic doublet at $\delta 7.28(\mathrm{H}-5)$ in the NOESY spectrum, and exhibited ${ }^{3} J$ HMBC correlation to C-4 ( $\delta$ 150.8), confirmed the attachment of glucose moiety to the carbon $\mathrm{C}-4$. Thus, 4 was concluded to be 3-dihydrocoumaroyloxy-4- $O$ - $\beta$-D-glucopyranosyl- $p$-coumaric acid and trivially named as spiraformin $\mathrm{D}$.

In addition, spiraeaine A (5), ${ }^{27)} \beta$-sitosterol (6), ${ }^{27)}$ bakuchiol (7), ${ }^{27)}$ glutinol (8), ${ }^{27)} \beta$-amyrin (9), ${ }^{23)} \beta$-sitosterone (10), ${ }^{28)}$ mixture of $\beta$-sitosterol (6) and stigmasterol (11), ${ }^{27)}$ methyl vanillate $(\mathbf{1 2}){ }^{29)}$ methyl ferulate $(\mathbf{1 3}){ }^{30)}$ ethyl $p$-hydroxy-trans-cinnamate (14), ${ }^{31)}$ ethyl ferulate (15), ${ }^{32)}$ agrimonolide (16), ${ }^{33)}$ aurantiamide acetate $(\mathbf{1 7}),{ }^{34)} \beta$-sitosteryl glucoside (18), ${ }^{27)}$ nonadecyl ferulate $(\mathbf{1 9}),{ }^{27)}$ nonadecyl-3-(4hydroxyphenyl)propionate $(\mathbf{2 0}),{ }^{35)}$ uridine $(\mathbf{2 1}),{ }^{36)} 3-O-\beta$-Dglucoside- $p$-vanillic acid (22), ${ }^{37)}$ vanillic acid $(\mathbf{2 3}),{ }^{26)} p$-hydroxybenzoic acid (24), ${ }^{38)}$ veratric acid (25), ${ }^{38)}$ syringic acid (26), ${ }^{39)} 3-O-\beta$-D-glucoside-4',5-dihydroxystilbene $(27),{ }^{40)}$ $p$-hydroxybenzaldehyde $(\mathbf{2 8}),{ }^{27)}(-)$-isolariciresinol-3a- $O$ - $\beta$ D-glucopyranoside (29), ${ }^{26)}$ methyl quinate $(\mathbf{3 0}),{ }^{41)}$ quercetin3- $O$ - $\beta$-D-glucopyranoside (31), ${ }^{42)}$ quercetin-3- $O-\beta$-D-galactopyranoside (32), ${ }^{42)}$ kaempferol-3- $O$ - $\beta$-D-glucopyranoside $\left.(33),{ }^{42}\right) p$-coumaric acid (34), ${ }^{42)} 3,4^{\prime}, 5$-trihydroxystilbene (35), ${ }^{26)} p$-hydroxycinnamaldehyde (36), ${ }^{43)}$ quercetin $(37),{ }^{42}$ (+)-5,7-dihydroxy-2-(3',4'-methylenedioxyphenyl)chroman4-one (38), ${ }^{44)}$ and $N, N$-dimethyladenine $(\mathbf{3 9})^{45)}$ were also identified by comparison of their physical and spectral data with those reported in the literature.

\section{Experimentaøl}

General Experimental Methods Melting points were measured on Yanaco MP-S3 micro-melting point apparatus and uncorrected. ${ }^{1} \mathrm{H}-$ and ${ }^{13} \mathrm{C}$-NMR spectra were obtained on the Bruker Avance-300 and AMX-400 NMR spectrometers, with tetramethylsilane (TMS) as internal standard. IR spectra were determined as $\mathrm{KBr}$ discs on a Shimadzu FTIR-8501 spectrophotometer, and UV spectra were recorded in $\mathrm{MeOH}$ on a Hitachi UV3210 spectrophotometer. EI- and HR-EI-MS were measured with a $70 \mathrm{eV}$ direct inlet system on a VG 70-250S spectrometer, and the FAB- and HR-
FAB-MS were obtained on a Jeol JMS-700 spectrometer. Optical rotations were determined on a Jasco DIP-370 digital polarimeter.

Plant Material Stems of $S$. formosana was collected in Ilan Hsien, Taiwan, Republic of China, in 1991. A voucher specimen (Wu 1991010) is deposited in the Herbarium of National Cheng Kung University, Tainan, Taiwan.

Extraction and Isolation The fresh stem $(8.6 \mathrm{~kg})$ of $S$. formosana was powdered and extracted with hot EtOH $(10 \mathrm{~L} \times 7)$. The combined extracts were concentrated to give dark brown syrup $(1.01 \mathrm{~kg})$ and it was partitioned with $\mathrm{CHCl}_{3}$ and $n$-BuOH, successively, to afford four individual portions: $\mathrm{CHCl}_{3}$ layer $(320 \mathrm{~g}), n$-BuOH layer $(220 \mathrm{~g}), \mathrm{H}_{2} \mathrm{O}$ layer $(290 \mathrm{~g})$, and residue $(180 \mathrm{~g})$. The condensed $\mathrm{CHCl}_{3}$ solubles were subjected to alkaloids extraction using $3 \% \mathrm{HOAc}$ and $5 \% \mathrm{NH}_{4} \mathrm{OH}$ to yield a crude alkaloid extract $(9.2 \mathrm{~g})$. It was chromatographed over silica gel and with a gradient of $\mathrm{CHCl}_{3}$ and $\mathrm{MeOH}$ to afford 6 fractions. Fraction 5 was further purified by HPLC [Cosmosil 5C-18-AR-II Waters $(5 \mu \mathrm{m})$ ] with $\mathrm{MeOH}-\mathrm{H}_{2} \mathrm{O}(60: 40)$ to give 5 $(5.7 \mathrm{mg})$. The non-alkaloidal fraction was chromatographed on silica gel by eluting with gradient of $n$-hexane and EtOAc, to give 10 fractions. Fraction 2 was subjected to chromatography on a silica gel column with $n$-hexane and $\mathrm{C}_{6} \mathrm{H}_{6}(19: 1)$ eluent followed by recrystallization of a subfraction obtained to give $6(7.2 \mathrm{~g})$. Fraction 3 was repeatedly column chromatographed over silica gel with $n$-hexane and $\mathrm{CHCl}_{3}(9: 1)$ to yield $7(16.2 \mathrm{mg})$ and $\mathbf{8}(3.8 \mathrm{~g})$. Recrystallization of fourth fraction with $\mathrm{C}_{6} \mathrm{H}_{6}$ afforded $9(5.8 \mathrm{~g})$. Fraction 5 on a silica gel column chromatography with a gradient of $n$-hexane and $\left(\mathrm{CH}_{3}\right)_{2} \mathrm{CO}$ afforded $\mathbf{1 0}(23.7 \mathrm{mg})$ and a mixture of $\mathbf{6}$ and $\mathbf{1 1}(4.8 \mathrm{~g})$. Silica gel column chromatography of fraction 6 and followed by PTLC purification with the mixture of $n$-hexane and $\left(\mathrm{CH}_{3}\right)_{2} \mathrm{CO}(5: 1)$ resulted in $\mathbf{3}(1.3 \mathrm{mg}), \mathbf{1 2}$ $(13.6 \mathrm{mg}), \mathbf{1 3}(17.4 \mathrm{mg}), \mathbf{1 4}(47.6 \mathrm{mg})$, and $\mathbf{1 5}(67.8 \mathrm{mg})$. Fraction $7 \mathrm{on}$ a silica gel column chromatography with $\mathrm{C}_{6} \mathrm{H}_{6}$ and $\left(\mathrm{CH}_{3}\right)_{2} \mathrm{CO}(19: 1)$ followed by purification of subfractions 2 and 3 by PTLC with $n$-hexane and $\left(\mathrm{CH}_{3}\right)_{2} \mathrm{CO}(19: 1)$ afforded $\mathbf{1}(9.8 \mathrm{mg})$ and $\mathbf{2}(1.1 \mathrm{mg})$. Purification of fraction 8 and 9 by repeated silica gel column chromatography using $\mathrm{C}_{6} \mathrm{H}_{6}$ and EtOAc $(15: 1)$, and $\mathrm{CHCl}_{3}$ and $\mathrm{MeOH}(20: 1)$ gave $\mathbf{1 6}(5.6 \mathrm{mg}), 17$ $(20.5 \mathrm{mg})$, and $\mathbf{1 8}(36.3 \mathrm{mg}), \mathbf{1 9}(37.5 \mathrm{mg})$ and $\mathbf{2 0}(18.9 \mathrm{mg})$, respectively.

The $n$ - $\mathrm{BuOH}$ layer $(220 \mathrm{~g})$ was subjected to column chromatography on Diaion HP-20, and eluted with a step gradient of $\mathrm{H}_{2} \mathrm{O}$ and $\mathrm{MeOH}$ to give 12 fractions. Recrystallization of third fraction with $\mathrm{MeOH}$ afforded 21 $(9.6 \mathrm{mg})$. Fraction 4 was separated by column chromatography on a silica gel column with a mixture of EtOAc and $\mathrm{MeOH}(8: 1)$ saturated with $\mathrm{H}_{2} \mathrm{O}$ to afford $22(15.3 \mathrm{mg})$ and $\mathbf{2 3}(12.3 \mathrm{mg})$. Fraction $5 \mathrm{on}$ a silica gel column chromatography with EtOAc and $\mathrm{MeOH}(10: 1)$ saturated with $\mathrm{H}_{2} \mathrm{O}$ followed by recrystallization of subfraction 3 in acetone gave $24(17.5 \mathrm{mg})$. Purification of fraction 6 on silica gel column chromatography with EtOAc- $\mathrm{MeOH}-\mathrm{H}_{2} \mathrm{O}$ (15: 1 : sat) eluent resulted in the isolation of $\mathbf{2 5}(18.3 \mathrm{mg})$ and $\mathbf{2 6}(21.6 \mathrm{mg})$. Fraction 7 was recrystallized to afford $27(27.3 \mathrm{mg})$. A series of silica gel column chromatography of fraction 8 by $\mathrm{CHCl}_{3}-\mathrm{MeOH}-\mathrm{H}_{2} \mathrm{O}(5: 1:$ sat $)$ with a step gradient of $\mathrm{MeOH}$ yielded $28(15.3 \mathrm{mg}), 29(208.5 \mathrm{mg}), \mathbf{3 0}$ $(21.4 \mathrm{mg}), \mathbf{3 1}(98.3 \mathrm{mg}), \mathbf{3 2}(132.8 \mathrm{mg})$, and $\mathbf{3 3}(78.8 \mathrm{mg})$, successively. Compound $34(26.1 \mathrm{mg})$ was obtained from fraction 9 on silica gel column chromatography using $\mathrm{CHCl}_{3}$ and $\mathrm{MeOH}(10: 1)$ saturated with $\mathrm{H}_{2} \mathrm{O}$. Fraction 10 was subjected to chromatography on a silica gel column repeatedly with EtOAc- $\mathrm{MeOH}-\mathrm{H}_{2} \mathrm{O}(15: 1$ : sat) to give $\mathbf{3 5}(17.8 \mathrm{mg})$ and $\mathbf{3 6}(7.8 \mathrm{mg})$. Recrystallization of fraction 11 with EtOAc- $\mathrm{MeOH}$ solvent system resulted 37 (13.2 mg). Repeated column chromatography of fraction 12 on silica gel by $\mathrm{CHCl}_{3}-\mathrm{MeOH}-\mathrm{H}_{2} \mathrm{O}(8: 1:$ sat $)$ yielded $4(9.3 \mathrm{mg})$ and $\mathbf{3 8}(26.7 \mathrm{mg})$.

The water layer $(290 \mathrm{~g})$ was directly chromatographed on Diaion HP-20 column and eluted with a gradient of $\mathrm{H}_{2} \mathrm{O}$ and $\mathrm{MeOH}$ to give 10 fractions. Among them, fraction 5 was further purified by HPLC [Cosmosil 5C-18AR-II Waters $(5 \mu \mathrm{m})]$ with $\mathrm{MeOH}-\mathrm{H}_{2} \mathrm{O}(40: 60)$ to give $39(17.2 \mathrm{mg})$.

Spiraformin A (1): Colorless syrup. ${ }^{1} \mathrm{H}-$ and ${ }^{13} \mathrm{C}-\mathrm{NMR}$ : see Table 1. IR $(\mathrm{KBr}) \mathrm{cm}^{-1}: 3426,2927,1710,1635,1509,1439,1216$. UV $\lambda_{\max }(\mathrm{MeOH})$ $\mathrm{nm}(\log \varepsilon): 313,223$. HR-EI-MS $m / z: 356.1259$ (Calcd for $\mathrm{C}_{20} \mathrm{H}_{20} \mathrm{O}_{6}$ : 
356.1260). EI-MS m/z: $356\left(\mathrm{M}^{+}\right), 325,296,284,283,281$.

Spiraformin B (2): Colorless syrup. ${ }^{1} \mathrm{H}-$ and ${ }^{13} \mathrm{C}-\mathrm{NMR}$ : see Table 1 . IR $(\mathrm{KBr}) \mathrm{cm}^{-1}: 3375,2923,1723,1604,1510,1443,1220$. UV $\lambda_{\max }(\mathrm{MeOH})$ $\mathrm{nm}(\log \varepsilon): 286$. HR-EI-MS $m / z$ : 370.1414 (Calcd for $\mathrm{C}_{21} \mathrm{H}_{22} \mathrm{O}_{6}: 370.1416$ ). EI-MS $m / z: 370\left(\mathrm{M}^{+}\right), 363,349,329,315,283,241,226,121$.

Spiraformin C (3): Colorless syrup. ${ }^{1} \mathrm{H}-$ and ${ }^{13} \mathrm{C}-\mathrm{NMR}$ : see Table 1. IR $(\mathrm{KBr}) \mathrm{cm}^{-1}: 3374,2920,1724,1603,1509,1428,1223$. UV $\lambda_{\text {max }}(\mathrm{MeOH})$ $\mathrm{nm}(\log \varepsilon): 312,222$. HR-EI-MS m/z: 398.1713 (Calcd for $\mathrm{C}_{23} \mathrm{H}_{26} \mathrm{O}_{6}$ : 398.1729). EI-MS $m / z: 398\left(\mathrm{M}^{+}\right), 365,342,316,283,121$.

Spiraformin D (4): Colorless syrup. $[\alpha]_{\mathrm{D}}^{25}:-2.1^{\circ}(c=0.9, \mathrm{MeOH}) .{ }^{1} \mathrm{H}-$ and ${ }^{13} \mathrm{C}-\mathrm{NMR}$ : see Table 1. IR ( $\left.\mathrm{KBr}\right) \mathrm{cm}^{-1}: 3464,2366,1695,1626,1424$, 1211. UV $\lambda_{\max }(\mathrm{MeOH}) \mathrm{nm}(\log \varepsilon): 289,222$. HR-FAB-MS $m / z: 491.1554$ (Calcd for $\left.\mathrm{C}_{24} \mathrm{H}_{27} \mathrm{O}_{11}: 491.1553\right)$. FAB-MS $m / z: 491\left([\mathrm{M}+\mathrm{H}]^{+}\right), 490$

Acknowledgements The authors are grateful to the National Science Council, Taiwan, R.O.C. (NSC 93-2113-M-006-001) for financial support for this research and also thankful to the National Research Institute of Chinese Medicine, R. O. C., for partial financial support of this research. Authors are also thankful to Dr. C. J. Chou, National Research Institute of Chinese Medicine, R. O. C., for the collection and identification of plant materials.

\section{References}

1) Ohashi H., Hsieh C. F., "Flora of Taiwan," Vol. 3, 2nd ed. by Editorial Committee of the Flora of Taiwan, Taipei, 1993, p. 149.

2) Jiangsu New Medical College, "Zhongyao Dacidian (A Dictionary of Traditional Chinese Medicine)," Shanghai Science and Technology Publishing House, Shanghai, 1977, pp. 1117-1118 and p. 1978.

3) Xie Z. W., "Quanguo Zhongcaoyao Huibian (A Collection of Chinese Herbal Drugs)," 2nd ed., People's Hygenic Publishing House, Beijing, 1996 , pp. $514-515$ and p. 767.

4) Ro J. S., Kor. J. Pharmacol., 13, 39-42 (1982).

5) Woo M. H., Lee E. H., Chung S. O., Kim C. W., Kor. J. Pharmacol., 27, 389-396 (1996)

6) Shen Z. Q., Chen Z. H., Li L., Lei W. Y., Hao X. J., Planta Med., 66, 287-289 (2000)

7) So H. S., Park R., Oh H. M., Pae H. O., Lee J. H., Chai K. Y., Chung S. Y., Chung H. T., J. Ethnopharmacol., 68, 209-217 (1999).

8) So H. S., Park R., Oh H. M., Chai K. Y., Lee J. H., Chung H. T., Immunopharmacol. Immunotoxicol., 21, 343-355 (1999).

9) Morita S., Ito M., Fujii Y., Harada J., J. Weed Sci. Tech., 46, 134-135 (2001).

10) Node M., Hao X. J., Zhou J., Chen S. Y., Taga T., Miwa Y., Fuji K., Heterocycles, 30, 635-643 (1990)

11) Hao X. J., Zhou J., Fuji K., Node M., Chin. Chem. Lett., 3, 427-430 (1992).

12) Hao X. J., Node M., Zhou J., Chen S. Y., Taga T., Miwa Y., Fuji K., Heterocycles, 36, 825-831 (1993).

13) Hao X. J., Hong X., Yang X. S., Zhao B. T., Phytochemistry, 38, 545547 (1995)

14) Hong X., Nie J. L., Hao X. J., Chin. Chem. Lett., 7, 133-134 (1996)

15) Nie J. L., Hao X. J., Phytochemistry, 48, 1213-1215 (1998).
16) Wang B. G., Lin L., Yang X. S., Chen Z. H., Hao X. J., Heterocycles, 53, 1343-1350 (2000)

17) Pelletier S. W., Mody N. V., J. Nat. Prod., 43, 41-71 (1980).

18) Li L., Nie J. L., Shen Z. Q., Wu W. L., Chen Z. H., Hao X. J., Planta Med., 67, 142-145 (2001).

19) Bodalski T., Cisovski W., Diss. Pharm. Pharmacol., 21, 443-445 (1969).

20) Sennikov G. A., Makarova G. V., Komisarenko M. F., Farm. Zh., 24, 75-79 (1969).

21) Goto G., Sasaki K., Sakahe N., Hirata Y., Tetrahedron Lett., 9, 13691373 (1968).

22) Hao X. J., Nie J., Sun H. D., Gu Z. J., Yunnan Zhiwu YanJiu, 19, $297-$ 303 (1997)

23) Chou C. J., Wang C. B., Lin L. C., J. Chin. Chem. Soc., 24, 195-198 (1977).

24) Oh H., Oh G. S., Seo W. G., Pae H. O., Chai K. Y., Kwon T. O., Lee Y. H., Chung H. T., Lee H. S., J. Nat. Prod., 64, $942-944$ (2001).

25) Katase T., Bollag J. M., Soil Sciences, 151, 291-296 (1991).

26) Wang M., Li J., Rangarajan M., Shao Y., Lavoce E. J., Huang, T. C., J. Agric. Food Chem., 46, 4869-4873 (1998).

27) Wu T. S., Hwang C. C., Kuo P. C., Damu A. G., Chou C. J., Chen C. F., Heterocycles, 57, 1495-1500 (2002).

28) Wu T. S., Chan Y. Y., J. Chin. Chem. Soc., 41, 209-212 (1994).

29) Wu T. S., Ou L. F., Teng C. M., Phytochemistry, 36, 1063-1068 (1994).

30) Machida K., Kikuchi M., Phytochemistry, 41, 1333-1336 (1995).

31) Talapatra S. K., Mukhopadhyay S. K., Talapatra B., Phytochem. Rep., 1974, 836-837 (1974)

32) Bhadari S. P. S., Mishra A., Roy R., Garg H. S., Phytochemistry, 31, 689-691 (1992).

33) Arakawa H., Torimoto N., Masui Y., Tetrahedron Lett., 38, 41154117 (1968).

34) Paknikar S. K., Kirtany J. K., Naik C. G., Indian J. Chem., 13, 1234 1236 (1975).

35) Kuo Y. H., Yu M. T., Phytochemistry, 42, 779-782 (1996).

36) Kitajima J., Kamoshita A., Ishikawa T., Takano A., Fukuda T., Isoda S., Ida Y., Chem. Pharm. Bull., 51, 673-678 (2003).

37) Ayiyo S. K., Maksut C. K., Takashi H. K., Phytochemistry, 40, 257261 (1995).

38) Machida K., Kikuchi M., Phytochemistry, 41, 1333-1336 (1996).

39) Wu T. S., Yeh J. H., Wu P. L., Phytochemistry, 40, 121-124 (1995).

40) Nyemba A. M., Mpondo T. N., Kimbu S. F., Connolly J. D., Phytochemistry, 39, 895-898 (1995).

41) Takayama H., Ohmori O., Sakai M., Funahashi M., Kitajima M., Heterocycles, 49, 49-52 (1998).

42) Lin L. C., Chou C. J., Yang L. M., Chin. Pharm. J., 51, 299-305 (1999).

43) Barik B. R., Kundu A. K., Phytochemistry, 26, 2126-2127 (1987).

44) Ferreira E. O., Dias D. A., Phytochemistry, 53, 145-147 (2000).

$45)$ Wu T. S., Chang F. C., Wu P. L., Kuoh C. S., J. Chin. Chem. Soc., 42, 929-934 (1995). 